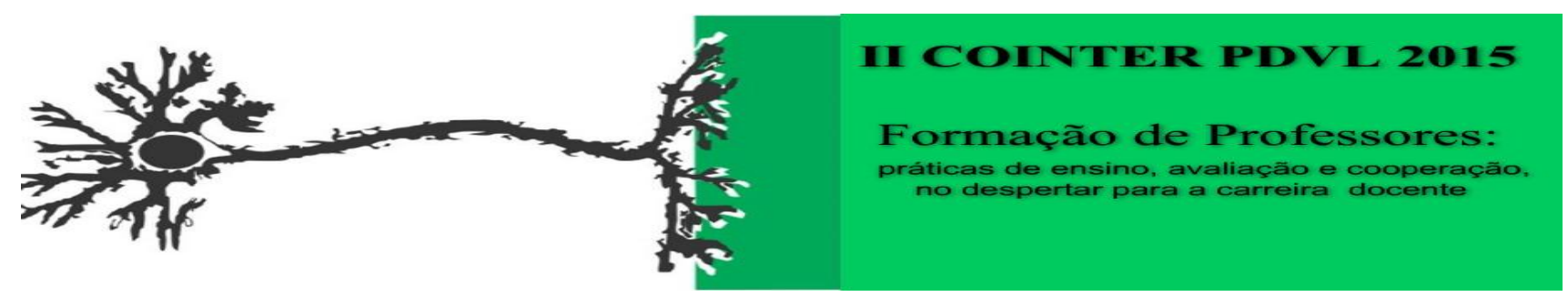

\title{
DESPERTANDO NOVOS TALENTOS E A FORMAÇÃO INICIAL DE PROFESSORES DE QUÍMICA EM ALAGOAS
}

\author{
Apresentação: Relato de Experiência \\ Jaqueline Quintino da Silva ${ }^{1}$; Elié Paula Predi Dornelas de Souza ${ }^{2}$ Joacy Vicente Ferreira $^{3}$
}

\section{Introdução}

A formação de professores de Ciências deve promover um maior interesse dos professores em instigar os estudantes a refletirem sobre as práticas que envolvem ciência e tecnologia na atualidade. Diante deste cenário, as contribuições de alguns programas fomentados pelo Ministério da Educação evidenciam a importância de ampliar as discussões sobre o caráter formador dessas práticas. O Programa Novos Talentos, regulamentado de acordo com a Portaria $n^{\circ} 173$, de 6 de dezembro de 2012, elucida aspectos pertinentes à extensão estabelecida entre as instituições de ensino superior (IES) e as escolas públicas brasileiras. Tais ações desempenham uma otimização na formação de professores, licenciandos e os estudantes, tendo em vista que "as propostas devem aproximar os cursos de graduação e pós-graduação das escolas públicas, contemplando o currículo da educação básica” (CAPES.GOV.BR, 2014).

\section{Relato de Experiência}

As atividades propostas por esse programa são promovidas de modo extracurricular, como Curso de Férias, contando com a participação dos licenciandos na monitoria da atividade no laboratório. Nesta ocasião, os alunos das escolas públicas de Maceió, no período de férias escolares, participam de atividades experimentais e de pesquisa nas dependências e laboratórios do Instituto Federal. Esses estudantes são do $9^{\circ}$ ano do ensino fundamental e ensino médio, que em momentos distintos desenvolvem experimentos de caráter investigativos e conhecem mais sobre os avanços tecnológicos. Os temas trabalhados são correlatos à realidade, tais como: o tratamento da água, as transformações químicas que ocorrem na cozinha, inclusive versando o uso de materiais usuais e os de laboratório.

\footnotetext{
${ }^{1}$ Licenciatura em Química, Instituto Federal de Alagoas, jaqueline.quintino6@gmail.com

${ }^{2}$ Licenciatura em Química, Instituto Federal de Alagoas, eliepaulap@ gmail.com

${ }^{3}$ Doutor em Química, Instituto Federal de Alagoas, joacyferreira@ifal.edu.br
} 
A experimentação articula habilidades imprescindíveis para a aprendizagem de conceitos químicos. Assim, os docentes apresentam os conhecimentos e avanços científicos numa perspectiva mais dinâmica da Ciência (Carvalho; Gil-Pérez, 2011, p. 25). Esse cenário proporciona aos alunos maior contato com o conhecimento científico. Já, para os licenciandos envolvidos, o planejamento dessas práticas ilustra a visão de sua profissão, pois quanto professores de química, deverão planejar momentos mais dinâmicos para o ensino de Química.

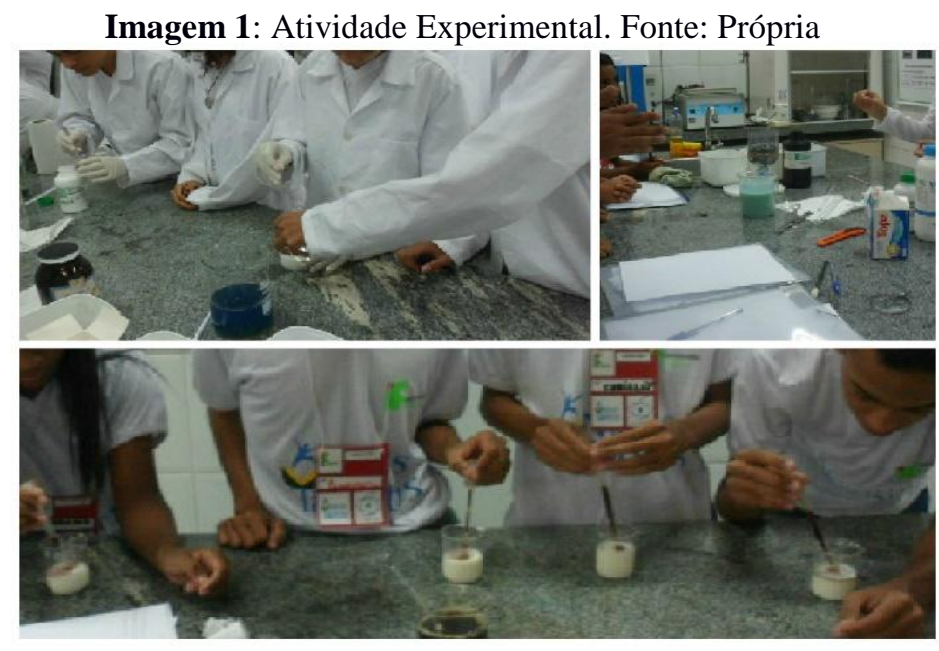

\section{Considerações}

Os licenciandos envolvidos em atividades que promovam maior aproximação à profissão docente serão impulsionados a desenvolverem práticas mais contextualizadas como professores no futuro. A proposta no programa supramencionado e desenvolvido no Instituto Federal de Alagoas enfatiza o aprimoramento na vivência acadêmico-profissional dos futuros professores formados no curso de Licenciatura em Química nesta mesma IES.

\section{Referências}

BRASIL. Portaria $n^{\circ} 173$, de 6 de dezembro de 2012. Aprova o Regulamento do Programa Novos Talentos.

CARVALHO, A. M. P.; GIL-PÉREZ, D. Formação de professores de ciências: tendências e inovações. 10. ed. v. 28. São Paulo: Cortez, 2011.

(FUNDAÇÃO CAPES). Programa Novos Talentos. Disponível em: http://www.capes.gov.br/educacao-basica/novos-talentos. Acesso em: 10/08/15. 